individual patient from those that are effective for her type of epilepsy.

(C) 2013 American Academy of Neurology

1. Hernandez-Diaz S, Smith CR, Shen A, et al, for the North American AED Pregnancy Registry, North American AED (Antiepileptic Drug) Pregnancy Registry, Scientific Advisory Committee, and North American AED Pregnancy Registry. Comparative safety of antiepileptic drugs during pregnancy. Neurology 2012;78:1692-1699.

2. Tran TA, Leppik IE, Blesi K, Sathanandan ST, Remmel R. Lamotrigine clearance during pregnancy. Neurology 2002; 59:251-255.

3. Nelson KB, Ellenberg JH. Maternal seizure disorder, outcome of pregnancy, and neurologic abnormalities in the children. Neurology 1982;32:1247-1254.

4. Mølgaard-Nielsen D, Hviid A. Newer-generation antiepileptic drugs and the risk of major birth defects. JAMA 2011; 305:1996-2002.

5. Morrow J, Russell A, Guthrie B, et al. Malformation risks of antiepileptic drugs in pregnancy: a prospective study from the UK Epilepsy and Pregnancy Register. J Neurol Neurosurg Psychiatry 2006;77:193-198.

6. Sabers A, Dam M, a-Rogvi-Hansen B, et al. Epilepsy and pregnancy: lamotrigine as main drug used. Acta Neurol Scand 2004;109:9-13.

7. Vajda F, Hitchcock A, Graham J, O’Brien T, Lander C, Eadie M. The Australian Register of antiepileptic drugs in pregnancy: the first 1002 pregnancies. Aust NZ J Obstet Gynaecol 2007;47:468-474.

8. Cunnington M, Ferber S, Quartey G; The International Lamotrigine Pregnancy Registry Scientific Advisory Committee. Effect of dose on the frequency of major birth defects following fetal exposure to lamotrigine monotherapy in an international observational study. Epilepsia 2007;48:1207-1210.

\section{PLASMA MULTIANALYTE PROFILING IN MILD COGNITIVE IMPAIRMENT AND ALZHEIMER DISEASE}

David A. Bennett, Chicago: In an elegant targeted proteomics study of 3 cohorts with more than 1,000 subjects, Hu et al. ${ }^{1}$ nominated several peripheral proteins associated with Alzheimer disease (AD).

There has long been an interest in identifying peripheral biomarkers for $\mathrm{AD}^{2}{ }^{2}$ Technological approaches to quantifying the proteome continue to improve, allowing the characterization of nearly 10,000 proteins from a single sample with about half of the proteins coded by the human genome. ${ }^{3}$ However, hurdles remain. First, experiences with the genome suggest there will be many false-positives that are not consistently replicated. Second, common diseases (e.g., cerebrovascular disease, Lewy body pathology) and other factorsincluding proteins - that promote resilience track with clinically and pathologically diagnosed $\mathrm{AD} .{ }^{4,5}$

Even the most carefully designed AD case-control studies will identify proteins associated with other diseases and resilience. Finally, determining whether proteins are resident in the human brain is essential for understanding their role in promoting cognitive impairment or maintaining cognition. Interestingly, one protein (interleukin-3) identified in the 2 discovery cohorts was identified in a targeted proteomics analysis of the human brain. ${ }^{5}$

Further study is needed but the human proteome is ripe for identifying novel therapeutic targets and biomarkers for $\mathrm{AD}$ and other neurologic diseases.

\section{Author Response: William T. Hu, Atlanta; David Holtzman, St. Louis; Leslie Shaw, John Trojanowski, Philadelphia; Holly Soares, New London, CT: We} agree with Dr. Bennett that determining the biological significance of CSF and blood biomarkers associated with $\mathrm{AD}$ represents the next logical step in developing these biomarkers further towards eventual clinical application. Along with interleukin-3, C-reactive protein (CRP) was found to be associated with plaques ${ }^{6}$ and higher CRP levels in successful cognitive aging individuals were recently linked to lower risks of dementia among their relatives. ${ }^{7}$ The connection to brain proteomic changes has also been observed. For example, altered CSF levels of fatty acid binding protein in 2 groups of patients with AD has been found ${ }^{8,9}$ and fatty acid binding protein showed region-specific alterations in proteomic studies of $\mathrm{AD}$ brains. ${ }^{10} \mathrm{While}$ we do not expect all biomarker changes in the blood and CSF to directly reflect pathologic changes in the brain, a direct or indirect connection between brain pathology and biomarkers provides a window into detrimental and neuroprotective activities at the cellular and synaptic levels. As replication is a significant challenge in targeted proteomic analysis (such as the work we presented) as well as mass spectrometrybased unbiased proteomic studies, we hope a tandem discovery-validation design will accelerate the discovery of correlated brain, CSF, and blood biomarkers.

(C) 2013 American Academy of Neurology

1. Hu WT, Holtzman DM, Fagan AM, et al. Plasma multianalyte profiling in mild cognitive impairment and $\mathrm{Alz}_{-}$ heimer disease. Neurology 2012;79:897-905.

2. The Ronald and Nancy Reagan Research Institute of the Alzheimer's Association and the National Institute on Aging Working Group. Consensus Report of the Working Group on molecular and biochemical markers of Alzheimer's disease. Neurobiol Aging 1998;19:109-116.

3. Vidal M, Chan DW, Gerstein M, et al; Workshop Participants. The human proteome: a scientific opportunity for transforming diagnostics, therapeutics, and healthcare. Clin Proteomics 2012;9:6.

4. Schneider JA, Arvanitakis Z, Leurgans SE, Bennett DA. The neuropathology of probable Alzheimer disease and mild cognitive impairment. Ann Neurol 2009;66:200-208.

5. Arnold SE, Louneva N, Cao K, et al. Cellular, synaptic, and biochemical features of resilient cognition in Alzheimer's disease. Neurobiol Aging 2013;34:157-168.

6. Iwamoto N, Nishiyama E, Ohwada J, et al. Demonstration of CRP immunoreactivity in brains of Alzheimer's disease: 
immunohistochemical study using formic acid pretreatment of tissue sections. Neurosci Lett 1994;117:23-26.

7. Silverman JM, Schmeidler J, Beeri MS, et al. C-reactive protein and familial risk for dementia: a phenotype for successful cognitive aging. Neurology 2012;79:1116-1123.

8. Hu WT, Chen-Plotkin A, Arnold SE, et al. novel CSF biomarkers for Alzheimer's disease and mild cognitive impairment. Acta Neuropathol 2010;119:669-678.
9. Craig-Schapiro R, Kihn M, Xiong C, et al. Multiplexed immunoassay panel identifies novel CSF biomarkers for Alzheimer's disease diagnosis and prognosis. PLoS One 2011;6:e18850.

10. Schonberger SJ, Edgar PF, Kydd R, et al. Proteomic analysis of the brain in Alzheimer's disease: molecular phenotype of a complex disease process. Proteomics 2001;1: 1519-1528.

\section{CORRECTION}

Levetiracetam in pregnancy: Results from the UK and Ireland epilepsy and pregnancy registers

In the article "Levetiracetam in pregnancy: Results from the UK and Ireland epilepsy and pregnancy registers" by E. Mawhinney et al. (Neurology $\left.{ }^{\circledR} 2013 ; 80: 400-405\right)$, there is an error in the body of the abstract and in table 1 . The polytherapy major congenital malformations (MCM) rate should read 5.56\% (3.54\%-8.56\%) rather than 6.47\% $(4.31 \%-9.60 \%)$. The authors regret the errors. 


\section{Neurology}

\section{Plasma multianalyte profiling in mild cognitive impairment and Alzheimer disease}

David A. Bennett, William T. Hu, David Holtzman, et al.

Neurology 2013;80;690-691

DOI 10.1212/01.wnl.0000427396.91304.3d

\section{This information is current as of February 11, 2013}

Updated Information \&

Services

References

Permissions \& Licensing

Reprints including high resolution figures, can be found at:

http://n.neurology.org/content/80/7/690.full

This article cites 10 articles, 2 of which you can access for free at: http://n.neurology.org/content/80/7/690.full\#ref-list-1

Information about reproducing this article in parts (figures,tables) or in its entirety can be found online at:

http://www.neurology.org/about/about_the_journal\#permissions

Information about ordering reprints can be found online: http://n.neurology.org/subscribers/advertise

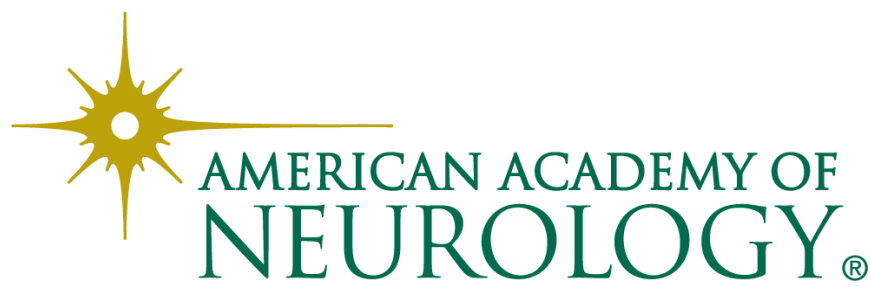

